overcome the counteraction to investigations involves several levels, where the recommendations concerning the necessity of criminological examination of normative acts in terms of the current anti-corruption legislation and the activation of the activities of the State Bureau of Investigation, provided that they are adequately staffed by the relevant personnel, are of a particular importance.

Key words: pre-trial investigation of excess of power or official authority by law enforcement officials, counteraction from interested persons, forms of counteraction to the investigation, subjects of counteraction to investigation, means of overcoming the counteraction to the investigation.

\title{
ОРГАНІЗАЦІЙНО-ПРАВОВІ ОСНОВИ ЗАХИСТУ ВЛАСНОСТІ ЗАСОБАМИ ОХОРОННОЇ ТЕХНІКИ В УКРАЇНІ
}

У статті розглянуто охоронну техніку як складову спеціальної техніки. Як наукова категорія охоронна техніка являє собою сукупність наукових положень $\mathrm{i}$ рекомендацій щодо застосування технічних, програмно-технічних, програмних засобів, речовин, інформаційних систем, наукових і спеціальних методів їх використання під час виконання завдань суб'єктами охоронної діяльності. Визначено систему та проблеми охоронної техніки.

Система охоронної техніки складається 3 таких елементів: загальних положень, напряму застосування та функціонального призначення засобів охоронної техніки. Виділено правові засади використання охоронної техніки та організаційні структури їі застосування для охорони об'єктів. Показано, що нормативно-правові акти, які становлять правову основу захисту майна та застосування технічних засобів охорони, належать до різних галузей права. Визначено категорію «організація технічної охорони об'єктів», ії класифікацію та перспективи розвитку.

Ключові слова: охоронна техніка, охоронна діяльність, категорія, класифікація, організація, перспектива.

Постановка проблеми. В Україні охорону об'єктів державної та інших форм власності здійснюють учасники ринку охоронних послуг, на якому діють поліція охорони та приватні охоронні структури. Забезпечення безпеки власності в сучасних умовах є особливо актуальним через зростання кваліфікованих злочинів, економічною нестабільністю, комп'ютерними злочинами, промисловим шпигунством.

Засоби захисту людини та ії майна розроблялися протягом тривалого періоду - від найпростіших засобів фізичного захисту житла людини до сучасних систем безпеки. Найбільшого поширення набули системи охоронно-пожежної сигналізації, застосування яких досить ефективно вирішує проблеми забезпечення безпеки за допомогою технічних засобів охорони.

(C) Хараберюш I. Ф., 2019 
Найбільш ефективним є комплексне вирішення завдання забезпечення безпеки об'єктів усіх форм власності з використанням інтегрованих систем 3 елементами інтелекту. Зазвичай до їх складу, крім систем охоронної й пожежної сигналізації, входять системи контролю й керування доступом і охоронного телебачення. В інтегрованих системах контроль і керування всіма технічними засобами здійснюють за допомогою передових інформаційних технологій з використанням сучасних апаратно-програмних засобів.

Динаміка світового розвитку апаратно-програмних засобів забезпечення комплексної безпеки об'єктів диктує необхідність не тільки вивчення сучасних технічних засобів охорони, але й відстеження тенденцій ïх розвитку в перспективі. Тому широке застосування сучасних систем безпеки для захисту об'єктів вимагає й відповідного підходу до організаційно-правового забезпечення захисту власності технічними засобами охорони.

Аналіз останніх досліджень і публікацій. Питання охорони об'єктів технічними засобами охорони досліджували такі науковці, як В. В. Волхонський [1], I. І. Груба [2], Р. Г. Магауєнов [3], П. В. Мокренко [4], В. О. Рижова [5], В. Г. Сінілов [6] та інші. Проте всі їх роботи мають певні розбіжності щодо визначення елементів технічних засобів охорони, улаштування охоронної сигналізації, принципів та організації ії побудови. Загалом не визначено місце охоронної техніки в системі технічних засобів, що використовуються в правоохоронній діяльності, а також потребують уточнення ії поняття та правові засади використання.

Формування цілей. Метою статті є визначення охоронної техніки як розділу спеціальної техніки, виділення ї поняття, завдання, системи, організаційно-правових основ використання для захисту власності та перспектив розвитку.

Виклад основного матеріалу. Охоронна техніка, що використовується суб'єктами охорони, є складовою більш широкого поняття «спеціальна техніка» загалом та «спеціальна техніка правоохоронних органів» зокрема. У наших попередніх дослідженнях ми дійшли висновку, що систему спеціальної техніки правоохоронних органів як галузі науки складають: криміналістична техніка, оперативна техніка, організаційна техніка, охоронна техніка [7, с. 25]. Тому треба враховувати, що охоронна техніка як складова спеціальної техніки поєднує, з одного боку, методи наукового пізнання свого предмета, a, 3 іншого - методи практичної діяльності відповідно з напрямом ії використання.

3 огляду на це можемо стверджувати, що охоронна техніка - це спеціальна техніка, яка використовується для охорони об'єктів різних форм власності.

Охоронна техніка як складова вчення про спеціальну техніку правоохоронних органів - це сукупність наукових положень і рекомендацій щодо застосування технічних, програмно-технічних, програмних засобів, речовин, інформаційних систем та природничо-наукових і спеціальних 
методів їх використання під час виконання завдань суб'єктами охоронної діяльності.

Як складова дисципліни «Спеціальна техніка правоохоронних органів» охоронна техніка має свій предмет - системи та види засобів, призначених для охорони об'єктів, організаційно-методичні, правові й тактико-технічні основи їх застосування й чітко визначені завдання:

1. Розкрити значення застосування науково-технічних засобів у діяльності суб'єктів охорони, спрямованої на захист власності.

2. Забезпечити засвоювання знань про природничо-наукові передумови, основні тенденції та проблеми впровадження й застосування засобів охоронної техніки; про форми та методи політики, яку проводить Україна щодо захисту права власності технічними засобами; про основні вимоги, напрями й заходи щодо забезпечення ефективного впровадження та використання засобів охоронної техніки; про перспективи розвитку охоронної техніки.

3. Забезпечити висвітлення та опанування певного комплексу організаційно-методичних, правових, тактико-технічних знань 3 урахуванням наявного передового досвіду під час навчання.

Як засіб охорони об'єктів охоронна техніка - це сукупність технічних засобів охорони (охоронно-технічні засоби, охоронна сигналізація) і методів, які правомірно використовуються для виявлення, фіксації, дослідження, оцінки та використання інформації щодо охорони об'єктів різних форм власності.

Аналіз думок певного кола науковців $[1 ; 2 . ; 3 ; 4 ; 6 ; 8]$, наші попередні дослідження [7; 9] та власний практичний досвід роботи в практичних підрозділах Державної служби охорони МВС України дають змогу дійти висновку, що завданнями охоронної техніки є:

- підвищення надійності захисту об'єктів, що охороняються;

- виявлення порушника й визначення місця його проникнення;

- контроль стану безпеки охоронюваних об'єктів;

- полегшення умов праці співробітників охорони;

- зниження чисельності особового складу охорони;

- зниження вартості охорони;

- підвищення рівня попередження та розслідування злочинів по «гарячих слідах» (крадіжки, розбійні напади);

- виконання завдань загальної профілактики правопорушень.

На нашу думку, систему охоронної техніки мають складати елементи, до яких входять загальні положення, галузь застосування та функціональне призначення засобів охоронної техніки. Загальні положення мають визначати основні поняття, завдання охоронної техніки, загальну характеристику технічних засобів охорони, прийомів i способів їх застосування, нормативно-правову регламентацію використання, значення в загальній системі охорони.

На наш погляд, а також на переконання значної кількості науковців, які досліджували цю проблему, технічні засоби охорони (охоронна 
сигналізація) за галуззю застосування поділяються на три групи: охоронні; пожежні; комбіновані (охоронно-пожежні).

Щодо функціонального призначення, то 3 цього питання немає однозначної позиції. Зокрема, В. Сінілов вважає, що система охоронної й тривожної сигналізації містить у собі: засоби виявлення - сповіщувачі, датчики; засоби тривожної сигналізації - кнопки, педалі, сповіщувачі; засоби збору, обробки й відображення інформації - приймально-контрольні прилади (ПКП), контрольні панелі, концентратори, комп'ютери, адресні й релейні модулі, світлові й звукові оповіщувачі тощо [6, с. 75].

О. Дементьєв та Г. Дементьєва вважають, що основу комплексу технічних засобів охорони становлять: засоби виявлення; технічні засоби спостереження; системи збору, обробки, відображення й документування інформації; засоби контролю доступу; допоміжні засоби й пристрої (блоки резервного електроживлення, переговірні пристрої тощо). Крім того, в особливо необхідних умовах застосовуються спеціальні засоби захисту інформації, пошуку техніки підслуховування, спостереження тощо, а також спеціальні засоби виявлення й знешкодження диверсійно-терористичних засобів [8, с. 24]. Ми вважаємо, що така класифікація дуже роздроблена й може бути спрощена з огляду на те, що окремі засоби охоронної техніки є універсальними та багатофункціональними пристроями й можуть об'єднати деякі з вказаних вище класифікаційних груп.

Автори курсу лекцій 3 дисципліни «Спеціальна техніка» кафедри кримінального права та митної справи Новосибірського державного аграрного університету вважають, що за функціональним призначенням засоби охоронно-пожежної сигналізації поділяються на три групи:

1) виявлення (сповіщувачі), призначені для одержання інформації про стан контрольованих параметрів (світловий промінь, СВЧ-поле, інфрачервоне випромінювання тощо);

2) сповіщення (приймально-контрольні прилади, оповіщувачі), призначені для приймання й перетворення службової й тривожної інформації й видачі оповіщення;

3) передачі інформації (системи передачі повідомлень у складі кінцевого пристрою, ретранслятору й пульту централізованого спостереження), призначені для передачі каналами зв'язку, обробки й зберігання інформації (повідомлень про проникнення, службових і контрольно-діагностичних повідомлень, а також для передачі й приймання команд телекерування) [10, с. 19]. Ця класифікація здається нам більш придатною для структурування системи охоронної техніки, але вона, на нашу думку, також не відповідає вимогам універсалізації та спрощення структурної конструкції.

Ми вважаємо, і це підтвердила багаторічна практика, що найбільш придатною для структурування охоронної техніки за функціональним призначенням є така класифікація:

- технічні засоби виявлення (датчики), призначені для одержання інформації про стан контрольованого параметра;

- технічні засоби сповіщення (ПКП, концентратори, пульти централізованого спостереження), призначені для прийому, перетворення, 
передачі, зберігання, обробки і відображення інформації, яка надходить від датчиків.

Своєю чергою, технічні засоби виявлення та сповіщення також поділяються за різними ознаками, маючи дуже великий перелік моделей і модифікацій. Зазначимо, що це має бути предметом обговорення та аналізу іншої роботи.

Автор надав узагальнену систему засобів охоронної техніки, яка дасть змогу більш обгрунтовано розглянути організаційно-правові основи охорони власності цими засобами.

Правова природа охорони права власності в нашій державі вимагає іiі реалізації в спосіб комплексного застосування організаційно-технічних інструментів. Як визначив І. Личенко, цьому сприяють нормативно-правові акти, що належать до різних галузей права:

- конституційного - ст. 41 Конституції України встановлює принцип, згідно з яким кожен має право володіти, користуватися і розпоряджатися своєю власністю, результатами своєї інтелектуальної, творчої діяльності. Ніхто не може бути протиправно позбавлений права власності. Право приватної власності є непорушним;

- господарського - ст. 133 Господарського кодексу України визначає, що держава забезпечує рівний захист майнових прав усіх суб'єктів господарювання (п. 3);

- цивільного - ст. 386 Цивільного кодексу України вказує, що держава забезпечує рівний захист прав усіх суб'єктів права власності (п. 1). Власник, права якого порушені, має право на відшкодування завданої йому майнової та моральної шкоди (п. 3);

- адміністративного - Глава 6 Кодексу України про адміністративні правопорушення визначає перелік адміністративних правопорушень, які посягають на право власності;

- кримінального - Розділ 6 Особливої частини Кримінального кодексу України визначає види діянь, які визнаються злочинами проти власності, та особливості відповідальності за них.

Система законодавства щодо охорони права власності охоплює:

- Закони України «Про Національну поліцію» (ст. 13), «Про охоронну діяльність»;

- акти Кабінету Міністрів: постанови Кабінету Міністрів України «Про заходи щодо вдосконалення охорони об'єктів державної та інших форм власності» (зі змінами) від 10.08.1993 № 615, «Питання забезпечення охорони об'єктів державної та інших форм власності» від 11.11.2015 № 937, «Питання функціонування органів поліції охорони як територіальних органів Національної поліції та ліквідації деяких територіальних органів Міністерства внутрішніх справ» (зі змінами) від 13.10.2015 № 834, «Про затвердження Ліцензійних умов провадження охоронної діяльності» від 18.11.2015 № 960, «Про затвердження переліку спеціальних засобів, придбання, зберігання та використання яких здійснюється суб'єктами охоронної діяльності» від 11.02.2013 № 97. 
Охорона права власності є одним із основних завдань Національної поліції України, що втілюються в спосіб створення умов, які унеможливлюють або ускладнюють спроби завдати шкоди чужій власності, знищити їі або незаконно привласнити, чи заволодіти нею. Особливе місце в системі нормативно-правового забезпечення охорони права власності належить нормативно-правовим актам Національної поліції МВС України: «Про затвердження Положення про Департамент поліції охорони»: наказ Національної поліції України від 06.11.2015 № 43; «Про організацію охорони майна фізичних і юридичних осіб органами та підрозділами поліції охорони за допомогою засобів охоронного призначення»: наказ МВС України від 23.06.2017 № 533; «Перелік технічних засобів, рекомендованих для організації охорони об'єктів і діяльності органів поліції охорони»: наказ Департаменту поліції охорони від 04.08.2017 № 107.

У своїй роботі І. Личенко також визначає, що на державу покладено обов'язок щодо створення системи правових способів та засобів щодо підтримання режиму охорони права власності. Адміністративно-правовий режим охорони у сфері власності - це особливий порядок адміністративноправового регулювання, який відображає сукупність юридичних та організаційних засобів, що використовуються для закріплення правового стану відносин щодо володіння, користування та розпорядження майном і матеріального стану об'єктів права власності й спрямовані на забезпечення ïx стійкого функціонування [11, с. 19]. Тому потребує окремого розгляду організація використання охоронної (охоронно-пожежної) сигналізації для охорони власності.

Поняття «організація» широко вживається в багатьох науках (філософії, математиці, економіці, соціології тощо) і в практичній діяльності. Це поняття багатозначне. Найчастіше воно означає: внутрішню упорядкованість, узгодженість взаємозалежних елементів цілого (системи). Виходячи 3 цього значення організації, ми можемо стверджувати, що організація технічної охорони об'єктів - це комплексна система сертифікованих засобів виявлення, сповіщення та інших технічних засобів, призначена для створення необхідного рівня безпеки об'єкта i вирішення завдань, покладених на охоронну техніку під час ії експлуатації суб'єктами охорони відповідно до нормативних документів.

Практика показує, що застосування конкретної системи і типів технічних засобів охорони визначається вимогами суб'єктів охорони, кількістю об'єктів, що охороняються, та їх віддаленістю від пункту централізованої охорони (ПЦО), на який передається інформація від технічних засобів охорони.

За допомогою технічних засобів охорони можна організувати три види охорони:

1) автономну охорону об'єктів;

2) централізовану охорону об'єктів;

3) комбіновану охорону об'єктів.

Автономне встановлення технічних засобів охорони провадиться на окремо розташованому об'єкті охорони за допомогою ПКП, що встановлюється всередині об'єкта, датчиків, що до нього підключаються 
3'єднувальними лініями та світлових і звукових оповіщувачів, що встановлюють зовні в зручному для огляду місці.

Централізована охорона об'єктів організується за допомогою пультів централізованого спостереження, які встановлюються на ПЦО, по абонентських телефонних лініях або радіоканалу. До того ж об'єкти обов'язково мають бути оснащені технічними засобами охоронної та/або тривожної сигналізації.

Комбінована організація охорони об'єктів має на увазі певну комбінацію автономної й централізованої охорони. Наприклад, у робочий час об'єкт охороняється власними силами або силами сторонніх охоронних структур, а в неробочий час здається під охорону на ПЦО. Або цілодобово охороняється власною службою безпеки, але частина найбільш важливих приміщень об'єкта (сховище цінностей, кімнати зберігання зброї, наркотичних речовин тощо) одночасно охороняється за допомогою ПЦО або на ПЦО виведена тільки тривожна сигналізація об'єкта. Така організація охорони характерна для об'єктів кредитно-фінансової сфери (банки, ощадкаси, пункти обміну валюти тощо), великих компаній і організацій, а також органів влади.

Окремої уваги потребує питання перспективи розвитку систем охорони об'єктів. Одним з ключових напрямів удосконалення організації охорони є застосування інтелектуальних систем (IC).

Поняття «інтелектуальні системи» є похідним від категорії «інтелект» (лат. Intellectus - розум; розумові здібності людини). У сучасній літературі вона розглядається як сукупність або система пізнавальних здібностей людей, що виявляються в легкості навчання, здатності швидко і легко здобувати нові знання та вміння, в подоланні несподіваних перешкод, здатності знаходити вихід із нестандартної ситуації, умінні адаптуватися до складного, мінливого, незнайомого середовища, у глибині розуміння того, що відбувається, у творчості [12].

Виходячи з практики використання інтелектуальних систем, виділяємо такі інтелектуальні функції:

- комунікативні здібності - спосіб узаємодії системи 3 кінцевим користувачем і з іншою IC;

- аналітичні можливості - вирішення складних, погано формалізованих завдань, які вимагають побудови алгоритму вирішення залежно від конкретної ситуації, яка характеризується невизначеністю та динамічністю вихідних даних і знань;

- здатність до самонавчання - уміння системи автоматично отримувати знання $з$ накопиченого досвіду та застосовувати їх для вирішення завдань;

- адаптивність - здатність системи до розвитку відповідно з об'єктивними змінами галузі знань;

- здатність до самооцінки - володіння засобами для оцінки результатів власної роботи;

- творчість - охоплює складання віршів, комп'ютерної музики, ігор, винахід нових об'єктів. 
Кожній з перерахованих ознак умовно відповідає свій клас IC. Різні системи можуть мати одну або декілька ознак інтелектуальності з різним ступенем прояви.

Для охорони об'єктів найбільш перспективними напрямами можуть бути розвинення інтелектуальних систем відеоспостереження, інформаційнодовідкового забезпечення та систем централізованої охорони об'єктів.

Функціональність усього об'єктного програмного забезпечення інтелектуальних систем відеоспостереження поділяється на дві великі групи: розпізнавання та класифікація об'єктів відеоспостереження; відстеження шляху об'єкта відеоспостереження. Цей напрям потребує вдосконалення та розвитку в системі правоохоронних органів загалом і охоронних структур зокрема.

Розвинення інформаційно-довідкового забезпечення охоронної діяльності пов'язано з появою геоінформаційних систем (ГІС), які надають інформацію про просторове розміщення об'єктів з використанням карт або планів, що дуже важливо для своєчасної протидії злочинним проявам проти власності.

До IC охорони об'єктів можна віднести системи централізованої охорони, наприклад, «Орлан», «КРОНОС», «АІ-Грифон» тощо, які, по суті, представляють комплекс технічних засобів і програмного забезпечення для централізованого спостереження за станом пристроїв охоронної та пожежної сигналізації 3 використанням стільникової мережі GSM-900/1800 та проводових ліній АТС. Як і всі інші, цей напрям розробки IC потребує дальшого розвинення та вдосконалення.

Висновки. Підбиваючи підсумок, можемо констатувати, що охоронна техніка може розглядатися як складова вчення «спеціальна техніка правоохоронних органів», розділ дисципліни «Спеціальна техніка правоохоронних органів», засіб діяльності суб'єктів охорони щодо захисту власності. Охоронна техніка має чітко визначені завдання та свою систему, до якої входять загальні положення, галузь застосування та функціональне призначення засобів охоронної техніки.

Комплексному застосуванню технічних засобів охорони сприяють нормативно-правові акти, що належать до різних галузей права. Це, своєю чергою, стимулює розвиток організації використання охоронної техніки, яка складається з автономної, централізованої та комбінованої охорони об'єктів різних форм власності, сприяючи впровадженню в охорону інтелектуальних систем.

\section{Використані джерела:}

1. Волхонский В. В. Устройства охранной сигнализации : 2-е изд., доп. и перераб. СПб. : Экополис и культура, 2000. 312с.

2. Груба И. И. Системы охранной сигнализации. Технические средства обнаружения. Москва: СОЛОН-ПРЕСС, 2012. 220 с.

3. Магауенов Р. Г. Системы охранной сигнализации: основы теории и принципы построения : учебное пособие для вузов : 2-е изд., перераб. и доп. Москва: Горячая линия-Телеком, 2008. 496 с. 
4. Мокренко П. В. Елементи і пристрої фізичної та електронної охорони об'єктів. Львів: Фенікс, 2000. 185 с.

5. Рыжова В. А. Проектирование и исследование комплексных систем безопасности. СПб: НИУ ИТМО, 2012. 157 с.

6. Синилов В. Г. Системы охранной, пожарной и охранно-пожарной сигнализации : учебник для нач. проф. образования : 5-е изд., перераб. и доп. Москва : Издательский центр «Академия», 2010. 512 с.

7. Хараберюш І. Ф.Протидія злочинності засобами спеціальної техніки: концептуальний підхід : монографія. Донецьк : Вид-во «Ноулідж», 2011. 362 с.

8. Дементьев А. Н., Дементьева Г. В. Технические средства охраны : учебное пособие. Томск: кафедра ТУ, ТУСУР, 2012. 119 с.

9. Хараберюш I. Ф. Спеціальна техніка в органах внутрішніх справ. Загальна частина : навчальний посібник : 4-е вид., перероб. і доп. Донецьк : Донецький юридичний інститут МВС України, 2013. 246 с.

10. Специальная техника : курс лекций. Новосибирск : кафедра КПтаМС НГАУ, 2015. 128 c.

11. Личенко I. O. Адміністративно-деліктні аспекти захисту права власності : монографія. Львів : Львівський державний університет внутрішніх справ, 2011. 216 с.

12. Всемирная энциклопедия. Философия. Москва : АСТ, 2001. 1312 с.

Стаття надіӥшла до редколегї 10.01.2019

Хараберюш И. Ф., доктор юридических наук, профессор, профессор кафедры права и публичного администрирования Мариупольского государственного университета (г. Мариуполь, Украина)

\section{Организационно-правовые основы защиты собственности средствами охранной техники в Украине}

Статья посвящена рассмотрению охранной техники как составной специальной техники. Как научная категория охранная техника представляет собой совокупность научных положений и рекомендаций по применению технических, программно-технических, программных средств, веществ, информационных систем, научных и специальных методов их использования при выполнении задач субъектами охранной деятельности. Определена система и проблемы охранной техники.

Система охранной техники состоит из элементов, а именно: общих положений, направления применения и функционального назначения средств охранной техники. Выделяются правовые основы использования охранной техники и организационные структуры ее применения для охраны объектов. Показано, что нормативно-правовые акты, которые составляют правовую основу защиты имущества и применения технических средств охраны, принадлежат к различным отраслям права. Определены категории «организация технической охраны объектов», ее классификация и перспективы развития.

Ключевые слова: охранная техника, охранная деятельность, категория, классификация, организация, перспектива.

Kharaberiush I. Organizational and Legal Bases of Property Protection by Means of Security Equipment in Ukraine

The article is devoted to the consideration of security equipment as a component of special equipment, specifically as a scientific category, a component of the relevant 
discipline and a means of protecting objects from unauthorized entry. As a scientific category, security equipment is a set of scientific statements and recommendations on the use of technical, software and hardware, software, substances, information systems, scientific and special methods of using them in the performance of tasks by subjects of security activity. The system and problems of security equipment are defined.

The security equipment system consists of elements, namely: general provisions, directions of application and functionality of security equipment. The legal basis for the use of security equipment and the organizational structures of its use for the protection of objects are highlighted. It is shown that the normative legal acts that constitute the legal basis for the protection of property and the use of technical means of protection belonging to various branches of law: constitutional, economic, civil, administrative, criminal. The categories "organization of technical protection of objects" and its classification are defined. The organization of technical protection of objects is a comprehensive system of certified detection, warning and other technical means designed to create the necessary level of object security and solve the tasks assigned to the security equipment during its operation by security subjects in accordance with regulatory documents.

Practice shows that the use of a specific system and types of technical means of protection is determined by the requirements of the subjects of protection, the number of protected and their distance from the point of centralized protection to which information is transmitted from technical means of protection. With the help of technical means of protection, you can organize three types of protection: autonomous, centralized; combined. A promising direction of development of security equipment are intelligent systems.

Key words: security equipment, security activity, category, classification, organization, perspective.

УДК 343.97

Христьян А. О.

судовий експерт сектору технічних досліджень документів та почерку відділу криміналістичних видів досліджень Запорізького Науково-дослідного експертнокриміналістичного изентру МВС України

(м. Запоріжжя, Україна)

\section{ЗАСТОСУВАННЯ НОВІТНІХ ТЕХНОЛОГЙ ДЛЯ ПОПЕРЕДЖЕННЯ ТА ПРОФІЛАКТИКИ ЗЛОЧИНІВ}

У статті з'ясовано значення технічних засобів для попередження, розкриття та профілактики злочинів. Наведено статистичні дані щодо аналізу стану злочинності в Україні за 2018 рік, а також подано технічні засоби профілактики злочинів. Зазначено про необхідність впровадження в Україні позитивного досвіду зарубіжних країн у застосуванні новітніх технологій.

Ключові слова: злочинність, злочин, профілактика, попередження, технічні засоби, криміналістична техніка, технології.

Постановка проблеми. Розмах і безкарність злочинності, застарілі технічні засоби попередження, розкриття та профілактики злочинів, не застосування новітніх технологій для попередження злочинів - ось що $є$ 